\title{
MEDIA SOSIAL DALAM PROSES PEMBELAJARAN DI PERGURUAN TINGGI
}

\author{
Oleh : \\ I Gusti Ngurah Triyana \\ Institut Hindu Dharma Negeri Denpasar \\ ngrtriyana@gmail.com
}

\begin{abstract}
ABSTRAK
Kementerian Komunikasi dan Informatika (Kemenkominfo) mengungkapkan pengguna internet di Indonesia saat ini mencapai 63 juta orang. Dari angka tersebut, 95 persennya menggunakan internet untuk mengakses jejaring sosial. Andreas Kaplan dan Michael Haenlein mendefinisikan media sosial sebagai "sebuah kelompok aplikasi berbasis internet yang membangun di atas dasar ideologi dan teknologi Web 2.0, dan yang memungkinkan penciptaan dan pertukaran user-generated contens. Fungsi aplikasi ini adalah untuk memudahkan manusia berinteraksi satu dengan lainnya. Aplikasi media sosial ada banyak, seperti facebook, twitter, instagram, dll. Fitur-fitur yang dikembangkan media sosial setiap hari disempurnakan oleh pengembangnya. Fiturfitur yang ada pada media sosial ini menentukan jenis/kelompok media sosial berdasarkan kegunaanya. Berikut ini adalah contoh media sosial dilihat dari fungsi atau kegunaanya : (1). Relationship Networks (2). Media Sharing Networks (3). Online Reviews (4). Forum Diskusi (5). Social Publishing Platforms (6). Bookmarking Sites (7). Interest-based networks (8). E-commerce. Media sosial sebagai bagian yang tidak dapat dipisahkan dari internet telah menjadi tren baru di masyarakat. Penggunaannya yang begitu masif juga dapat dimanfaatkan dalam mendukung proses pembelajaran di perguruan tinggi. Media sosial memiliki beberapa kelebihan diantaranya mudah untuk digunakan, membangun hubungan atau relasi, jangkauanya global, dan terukur. Selain e-learning, perguruan tinggi dapat memanfaatkan media untuk sharing materi, diskusi, maupun tanya jawab. Beberapa contoh pemanfaatan media sosial untuk menunjang proses pembelajaran : (1). Tugas Kelompok Menggunakan Grup Facebook; (2). Konferensi Video Kelas Menggunakan Google Hangouts; (3). The Flipped Classroom Menggunakan Youtube; (4). Jaringan Industri Menggunakan LinkelIn; (5) Q \& A Menggunakan Twitter / Reddit; (6) Penelitian dan Debat Menggunakan Quora; (7) Pengembangan Kesenian dan Kerajinan Tangan Pinterest.
\end{abstract}

Kata Kunci : Media Sosial, Pembelajaran.

\section{ABSTRACK}

The Ministry of Communications and Informatics (Kemenkominfo) revealed internet users in Indonesia currently reach 63 million people. Of that number, 95 percent use the internet to access social networking. Andreas Kaplan and Michael Haenlein define social media as än internet-based application group that builds on the foundation of Web 2.0 ideology and technology, and which enables the creation and exchange of user-generated content. 'The function 
of this application is to make it easier for humans to interact with each other. social media there are many, such as facebook, twitter, instagram, etc .. Features developed by social media every day is perfected by the developer. The features of this social media determine the type / group of social media based on its usefulness Here is a media example social media views of its function or function: (1) Relationship Networks (2) Media Sharing Networks (3) Online Reviews (4) Discussion Forums (5) Social Publishing Platforms (6) Bookmarking Sites (7) Interest-based networks (8) E-commerce Social media as an inseparable part of the internet has become a new trend in society. Its use are so massive can also be utilized in supporting the learning process in college. Social media has several advantages including easy to use, build relationships or relationships, global, and measurable. In addition to e-learning, universities can use the media for sharing material, discussion, and frequently asked questions. Some examples of the use of social media to support the learning process: (1). Group Tasks Using Facebook Groups; (2). Classroom Video Conferencing Using Google Hangouts; (3). The Flipped Classroom Using Youtube; (4). Industrial Networks Using LinkelIn; (5) $Q$ \& A Using Twitter / Reddit; (6) Research and Debate Using Quora; (7) Development of Arts and Crafts - Pinterest.

\section{PENDAHULUAN}

Dalam keseharian, saat berada di tempat-tempat umum seperti pasar, sekolah, dan rumah sakit, kita selalu melihat orang yang berada di tempat umum tersebut membawa dan mempergunakan handphone atau smartphone. Mereka begitu asyik membuka aplikasi media sosial yang terpasang pada smartphone yang dibawa. Beberapa kegiatan yang mereka lakukan menggunakan handphone atau smartphone adalah membuka aplikasi media sosial yang pada intinya melakukan beberapa hal seperti membaca status temannya di media sosial, mengomentari status temannya di media sosial, mengungkapkan apa yang mereka pikirkan pada status pribadinya. Kapanpun kita membuka aplikasi media sosial selalu ada status dan komentar yang baru. Hal ini menunjukkan bahwa setiap saat orangorang yang memiliki akun di media sosial melakukan update status maupun komentar. Semua profesi menggunakan media sosial untuk saling berinteraksi satu dengan lainnya.

Jumlah pengguna media sosial dari tahun ke tahun terus mengalami peningkatan. Kemajuan teknologi smartphone yang pesat dengan kecepatan untuk akses internet semakin baik menjadi pendorong semakin bertambahnya pengguna media sosial di seluruh dunia, termasuk Indonesia. Kementerian Komunikasi dan Informatika (Kemenkominfo) mengungkapkan pengguna internet di Indonesia saat ini mencapai 63 juta orang. Dari angka tersebut, 95 persennya menggunakan internet untuk mengakses jejaring sosial. (sumber : https://kominfo.go.id/ index.php/content/detail/3415/

Kominfo $+\%$

$\underline{3 \mathrm{~A}+\text { Pengguna }+ \text { Internet }+\mathrm{di}+\text { Indonesia }}$ $+63+$ Juta+Orang/0/berita satker,

diakses 28 pebruari 2018)

Di tahun 2012 saja ada 100 jejaring sosial, dan setiap menitnya terjadi: 100.000 tweets terkirim setiap menitnya, hampir 700.000 konten 
disebar di facebook, 3.600 gambar dishare pada Instagram, 2.000.000 kueri pada mesin pencari Google, setiap harinya didapati 600.000.000 view video Youtube versi Mobile. Rata-rata pengguna sharing tool Pinterest memiliki +/- 170 pins dan +/- 230 follower. Tidak ada media apa pun yang bisa menandingi antusiasme orang-orang dalam beraktivitas (Feri Sulianta, 2015:1)

Pengguna media sosial juga banyak memanfaatkan media sosial untuk mempromosikan produk barang dan jasa yang mereka jual. Media sosial dapat membantu para pelaku bisnis untuk melakukan promosi dengan biaya relatif murah. Bahkan ada fitur di media sosial yang berbayar, khusus untuk tujuan promosi. Pebisnis yang memanfaatkan fitur berbayar ini mendapatkan prioritas iklan produknya selalu muncul di haaman utama. Dengan pengguna aplikasi media sosial yang begitu besar membuat media sosial menjadi tempat yang sangat strategis, tepat dan efektif untuk berpromosi.

Mudahnya membagikan dan menerima informasi melalui media sosial menjadi sangat riskan dan berbahaya apabila digunakan oleh orang-orang yang tidak bertanggung jawab. Banyak sekali informasi yang dibagikan tidak dapat dipercaya kebenarannya. Hoax atau berita palsu, ujaran kebencian telah menjadi penomena yang meresahkan kita semua. Berita bohong dan ujaran kebencian yang berbau suku, agama, ras (SARA) dapat menggiring atau membuat opini kebencian pada kelompok masyarakat tententu yang dapat menimbulkan perpecahan di masyarakat. Media sosial sebagai produk teknologi informasi dan komunikasi mendapat tantangan baru untuk dapat membentuk peradaban yang adiluhung melaluii manfaat positif yang diberikan.

Di perguruan tinggi atau kampus kita juga dapat melihat penomena ini. Aplikasi media sosial yang merupakan produk dari teknologi informasi dan komunikasi, tidak saja dipakai untuk pemenuhan kebutuhan mereka untuk berinteraksi satu sama lain dengan tujuan bisa terus eksis. namun sebenarnya aplikasi ini dapat dimanfaatkan untuk saling berbagi informasi yang terkait drngan proses pembelajaran di kampus. Bagaimana media sosial dimanfaatkan sebagai penunjang kegiatan pembelajaran di perguruan tinggi atau kampus akan dijelaskan pada pembahasan.

\section{PEMBAHASAN}

\section{Media Sosial}

Andreas Kaplan dan Michael Haenlein mendefinisikan media sosial sebagai "sebuah kelompok aplikasi berbasis internet yang membangun di atas dasar ideologi dan teknologi Web 2.0, dan yang memungkinkan penciptaan dan pertukaran usergenerated content". (Kaplan, Andreas M.; Michael Haenlein, 2010, 59-68). Disebut sebagai kelompok aplikasi karena media sosial merupakan jenis aplikasi yang banyak diciptakan oleh pengembang aplikasi. Fungsi aplikasi ini adalah untuk memudahkan manusia berinteraksi satu dengan lainnya. Aplikasi media sosial ada banyak, seperti facebook, twitter, instagram, dll.

Sosial Media(sosmed) adalah sebuah media online, dimana para penggunanya bisa dengan mudah berpartisipasi dan saling berbagi informasi. Saat ini tidak ada satupun sosial media yang sama sekali tidak terhubung satu sama lain. Dan semakin banyak sosial media besar 
yang menawarkan fitur lebih dari sekedar komunikasi kepada pengguna. Penggunaan istilah Sosial Media pada media cetak pertama kali dipercaya dimulai pada tahun 1997. Saat itu seorang eksekutif di AOL bernama Ted Leonsis memberikan komentar bahwa organisasi tersebut perlu menyediakan konsumen "sosial media". "Sebuah tempat dimana mereka bisa dihibur, berkomunikasi, dan berpartisipasi dalam lingkungan sosial. Pada tahun yang sama situs jejaring sosial publik yang pertama, SixDegrees.com diluncurkan ke publik. Situs ini memperbolehkan pengguna untuk membuat halaman profil online dan daftar pertemanan. Kemudian pada dekade berikutnya, beberapa sosial media populer lain mulai bermunculan. Situs blogging seperti LiveJournal dan Blogger muncul tahun 1999, Wikipedia tahun 2001, social bookmarking Delicious dan jejaring sosial MySpace tahun 2003 kemudian disusul Facebook tahun 2004 (Hardy, https:// www.progresstech.co.id/blog/jenissosial-media, diakses 25 Pebruari 2018).

Fitur-fitur yang dikembangkan media sosial setiap hari disempurnakan oleh pengembangnya. Banyak sekali fitur-fitur yang tidak pernah dibayangkan sebelumnya kini dapat dinikmati dengan begitu mudahnya. Fitur-fitur yang ada pada media sosial ini menentukan jenis/kelompok media sosial berdasarkan kegunaanya. Berikut ini adalah contoh media sosial dilihat dari fungsi atau kegunaanya :

1. Relationship Networks

2. Media Sharing Networks

3. Online Reviews

4. Forum Diskusi

5. Social Publishing Platforms

6. Bookmarking Sites
7. Interest-based networks

E-commerce

\section{Relationship Networks}

Media sosial pada awalnya dikenal sebagai website yang digunakan untuk menjalin pertemanan atau relasi secara online, pertemanan secara online ini dibangun oleh mereka yang sudah saling kenal di dunia nyata dan dengan orang yang sama sekali belum dikenal. Media sosial yang tergolong kategori relationship Networks adalah Facebook, Linkedln, Google Plus dan lain sebagainya. Saat diluncurkan pertama kali fitur-fitur yang ada pada media sosial tersebut adalah halaman profil yang dilengkapi foto, biodata, serta informasi tambahan yang terkait dengan pengguna. Media sosial pada umumnya tidak berbayar atau gratis. Fitur-fitur yang ada memudahkan pengguna melakukan komunikasi dari satu tempat melalui dinding/walls, Timelines, dan Private Messages (PM). Pengguna juga dapat saling berbagi (sharing) informasi berupa teks, gambar dan video kepada seluruh jaringannya dengan satu kali klik. Jenis Relationship Networks ada beberapa seperti ada yang dihubungkan berdasarkan profesi atau pekerjaan penggunanya untuk saling berbagi informasi mengenai lowongan pekerjaan serta rekomendasi perusahaan, ada juga yang berfungsi seperti biro jodoh untuk mencari pasangan yang cocok, sesuai dengan kriteria yang diinginkan dan dari berbagai kota ataupun dari tempat sekitar pengguna berada. Relationship network ini juga sering digunakan untuk membangun pencitraan suatu produk (branding). Penjual suatu produk selalu berusaha terhubung dengan pembeli atau konsumennya melalui media sosial yang bisa dipergunakan untuk media pro- 
mosi, menerima order, serta menjawab pertanyaan mengenai produk yang dijual secara online.

\section{Media Sharing Networks}

Media sosial yang memiliki fungsi berbagi atau sharing kepada penggunanya, namun setiap media sosial memiliki konsentrasi yang berbeda dalam mengembangkan fitur-fiturnya. Berbagi video dapat dilakukan dengan baik sekali menggunakan Facebook dan Twitter, namun postingan berupa teks lebih mayoritas digunakan. Berbeda dengan facebook dan Twittter, media sosial yang lain yaitu Flickr atau Instagram, dan youtube lebih fokus dalam pengembangan konten visual. Pengguna diberikan kesempatan untuk mengedit gambar dan video sebelum diberi judul dan posting. Penggunaannya sebagai bisnis dan media pembelajaran di kampus perlu mempertimbangkan media apa yang dipergunakan membuat materi pembelajaran.

\section{Online Reviews}

Media sosial yang menggunakan teknologi Geolocation (geolokasi), sebuah sistem yang dipergunakan untuk menemukan atau melacak lokasi smartphone yang terhubung dengan internet. Teknologi ini semakin banyak diadopsi oleh media sosial karena kecanggihannya. Disematkannya teknologi ini oleh media sosial membuat penggunanya semakin mudah menemukan sebuah tempat yang telah mendapat review dan penilaian. Penilaian ini secara otomatis bermakna sebuah tempat itu menarik dan direkomendasi untuk dikunjungi. Situs online reviews banyak variannya, seperti digunakan oleh restoran, hotel dan perusahaan. Adanya online reviews membuat pengguna lebih mudah mem- pertimbangkan dan memutuskan untuk mengunjungi sebuah tempat, baik itu restoran, hotel, sekolah, rumah sakit, dan lain sebagainya. Aplikasi online seperti gojek, grab, uber sangat tergantung dengan penilaian dari konsumennya, karena ini dapat menunjukan kualitas layanan yang diberikan

\section{Forum Diskusi}

Sebelum berkembangnya media sosial seperti saat ini, forum diskusi telah banyak digunakan di internet. Pengguna internet berdiskusi di forum yang dibuatnya tentang apa saja sesuai dengan persamaan minat dan kelompoknya.Yahoogrups misalnya, pengguna internet dulu dapat menemukan banyak sekali forum diskusi, bahkan telah dikelompokan sesuai dengan minat dan lokasi. Pada masa lalu pengguna internet dapat berdiskusi di forum tanpa akun atau id yang dilengkapi dengan identitas yang asli. Maraknya berita bohong dan ujaran kebencian dewasa ini membuat registrasi pada forum-forum diskusi di internet menggunakan identitas yang asli.

\section{Social Publishing Platforms}

Social Publishing Platforms adalah blog dan microblog, dimana artikel yang ditulis dapat dibagikan untuk dibaca antara sesama pengguna. Platforms ini digunakan oleh media sosial untuk interaksi real-time seperti Twitter termasuk kategori microblogging. Berbeda dengan Medium dan Tumblr yang termasuk kategori interactive social publishing, berbeda dengan pendahulunya WordPress dan Blogger yang merupakan traditional blogging platforms. Usaha menjangkau pengguna yang lebih luas perlu mempertimbangka penggunaan kombinasi 
dari keduanya. Saat ini blogging menggunakan media video, yang sering disebut VLOG sangat popular karena didukung kemajuan kamera pada smartphone. membantu brand Anda menjadi penguasa di niche market yang ditargetkan.

\section{Bookmarking Sites}

Penggunaan internet dulu dan sekarang sangatlah berbeda. Sekarang menjadi lebih mudah digunakan hanya dengan menggunakan situs mesin pencari seperti google. Saat kita ingin mendapatkan gambaran saja, perlu mempergunakan bookmarking sites. Bookmarking Sites adalah web services seperti StumbleUpon, Pinterest dan Flipboard. Pengguna menggunakan website-website ini untuk mengumpulkan konten dari manapun di internet lalu menyimpannya didalam akun mereka. Konten yang mereka simpan dapat dalam bentuk gambar, video atau link website. Kumpulan konten-kon tersebut mereka beri judul dan label yang menjelaskan isi untuk mempermudah pengguna lain menemukannya. Konten yang disimpan, cara mengaksesnya dapat diatur apakah hanya dapat diakses secara pribadi ataukah dapat diakses oleh publik. Bookmarking Sites akan menyarankan content yang memiliki kemiripan dengan link website atau gambar yang pernah pengguna simpan sebelumnya. Bookmarking sebuah website memberikan keuntungan apabila website itu berhubungan dengan bisnis, apalagi jika dioptimasi dengan baik segingga website tersebut mudah ditemukan. Konten media pada website yang compatible dengan perangkat pengguna internet mempermudah diakses.

\section{Interest-based networks}

Media sosial yang jaringannya memiliki kesamaan minat. Selain Facebook Groups dan Linkedin Groups serta Google+ communities, masih ada banyak lagi media sosial lain yang bisa digunakan untuk komunitas. Last.fm salah satunya, adalah sosial media untuk musisi dan pendengar musik, sementara Goodreads yang diperuntukan bagi penulis dan pecinta buku. Serta ada IMDB dan Rotten Tomatoes yang menjadi tempat berkumpulnya para penggemar dan kritikus film. Keberhasilan usaha yang dilakukan dengan memanfaatkan media sosial ditentukan oleh bagaimana kita memilih media sosial yang tepat, yang sesuai antara produk atau usaha jasa yang kita jual dengan konsumen yang ada pada media sosial tersebut, contohnya adalah rumah penerbit buku yang memiliki konsumen para pecinta buku, dalam hal ini konsumen bisa digabungkan kedalam sebuah komunitas. Media sosial berbasis komunitas dan hobi adalah tempat yang potensial untuk membuat bisnis Anda sejalan dengan trend yang ada. Begitu juga dengan pemanfaatan media sosial untuk media pembelajaran pastilah komunitasnya berbeda.

\section{E-commerce}

Jenis media sosial yang lagi naik daun, memiliki fungsi memudahkan penggunakan melihat, memilih, dan membeli produk yang disukai hanya dengan menggunakan jari. Beberapa situs yang tergolong e-commerce adalah (1). Polyvore, sebuah situs yang menampilkan produk yang dikumpulkan dari berbagai penjual dalam sebuah marketplace. (2). Situs Etsy yang memperbolehkan UKM dan pengrajin lokal untuk menjual produk 
mereka secara online. Beberapa tahun terakhir fitur e-commerce telah banyak diadopsi oleh media sosial karena kecenderungan pengguna internet yang mulai terbiasa dengan berbelanja secara online (Hardy, https:// www.progresstech.co.id/blog/jenissosial-media, diakses 25 Pebruari 2018).

Aplikasi media sosial masingmasing memiliki fitur-fiturnya sendiri, namun dari segi fungsi memiliki kemiripan. Fitur yang memberikan layanan untuk sekelompok orang membangun grup yang sifatnya terbuka, tertutup dan rahasia juga banyak dikembangkan oleh aplikasi media sosial. Facebook sebagai salah satu aplikasi media sosial di internet juga mengembangkan fitur grup. Pembentukan grup biasanya dilakukan karena adanya kesamaan minat atau hobi, profesi, organisasi, sekolah, ataupun kepentingan lainnya. Setiap orang yang akan masuk menjadi anggota grup facebook harus memiliki akun di facebook. Fitur grup pada facebook ini dapat dijadikan pendukung untuk sharing materi pembelajaran yang diberikan dan dibahas pada kelas yang dikelola oleh Dosen. Materi pembelajaran ini pada umumnya berupa file dalam bentuk dokumen dengan format doc (word) maupun pdf, presentasi dalam format ppt (powerpoint), dan dapat juga berupa dokumen lainnya seperti file dengan format xls. Selain file yang dihasilkan oleh aplikasi microsoft, ada juga file jenis lain seperti file gambar dengan ektension jpg, gif, dan lain sebagainya. Semua materi pembelajaran berupa file tersebut dapat dibagikan oleh Dosen memanfaatkan konten-konten yang ada dalam aplikasi media sosial. Melihat sifat dari materi pembelajaran ini yang diperuntukan khusus untuk
Mahasiswa, maka supaya materi pembelajaran ini diberikan dengan tepat sasaran kepada Mahasiswa yang mengikuti kelas Dosen dimaksud, dapat dibuatkan grup khusus pada media sosial yang sifatnya tertutup. Mahasiswa yang ikut tergabung pada grup yang dibuat untu menunjang proses pembelajaran ini saja yang dapat menerima informasi berupa materi pembejaran yang dibagikan atau disharing melalui grup.

2. Media Pembelajaran di Perguruan Tinggi

Media adalah bentuk jamak dari medium yang berasal dari bahasa latin medius yang berarti tengah. Dalam bahasa Indonesia kata medium diartikan sebagai "antara' atau "sedang" (Latuheru, 1988: 14). Pengertian media pembelajaran menurut Latuheru (1988: 14) media pembelajaran adalah semua alat (bantu) atau benda yang digunakan untuk kegiatan belajar mengajar, dengan maksud menyampaikan pesan (informasi) pembelajaran dari sumber (guru maupun sumber lain) kepada penerima (dalam hal ini anak didik atau warga belajar). Pembelajaran adalah proses komunikasi antara pengajar, peserta didik, dan bahan ajar. Komunikasi tidak akan berjalan tanpa bantuan sarana penyampai pesan atau media. Jadi, sebagai alat bantu, media mempunyai fungsi melicinkan jalan menuju tercapainya tujuan pembelajaran (Syaiful Bahri Djamarah, 2005 : hal. 211). Berdasarkan pendapat ahli tersebut dapat disimpulkan bahwa media pembelajaran alat bantu untuk menyampaikan pesan dari sumber kepada penerima. Konteks pembelajaran sebarusnya meliputi ; (1) kerja mandiri dan berinteraksi dengan materi pembelajaran, (2) bekerja secara kolaborasi dongan teman pada tempat 
yangg berlainan baik secara serempak atau tidak, dimana kedua cara ini mungkin akan menjadi multimedia. (3). siswa akan magang kerja dan berinteraksi dengan para pekerja yang lebih berpengalaman supervisor atau instruktur (Hasanah Nur, 2008 : 439)

Dalam proses pembelajaran, banyak jenis media yang dapat dimanfaatkan untuk memproseskan bahan kajian. Mulai dari media yang sederhana, konvensional, dan murah harganya, hingga media yang kompleks, rumit, modern yang harganya sangat mahal. Mulai dari yang hanya merespons indera tertentu, sampai pada perpaduan dari berbagai indera manusia yang dapat di respons. Dari yang hanya secara manual dan secara konvensional dalam mengoperasikannya, hingga yang sangat tergantung pada perangkat keras dan kemahiran sumber daya manusia tertentu dalam mengoperasikannya. Jenis media yang lazim dipergunakan dalam pembelajaran antara lain : media non proyeksi, media proyeksi, media audio, media gerak, media komputer, komputer multi-media, hipermedia dan media jarak jauh (Heinich, Molenda, Russel, 1996 : 8). Departemen Pendidikan Nasional 2003, Mengelompokkan media menjadi 10 golongan sebagai berikut :

\begin{tabular}{|l|l|l|}
\hline $\begin{array}{l}\text { No } \\
1\end{array}$ & Golongan Media & Contoh Dalam Pembelajaran \\
\hline 2 & Cudio & $\begin{array}{l}\text { Kaset audio, siaran radio, CD, } \\
\text { telepon }\end{array}$ \\
\hline 3 & Audio-Cetak & $\begin{array}{l}\text { Buku pelajaran, modul, brosur, } \\
\text { leaflet, gambar }\end{array}$ \\
\hline 4 & $\begin{array}{l}\text { Kaset audio yang dilengkapi } \\
\text { bahan tertulis }\end{array}$ \\
\hline 5 & $\begin{array}{l}\text { Proyeksi Visual } \\
\text { Visual Diam }\end{array}$ & $\begin{array}{l}\text { Overhead transparansi (OHT), } \\
\text { film bingkai (slide) }\end{array}$ \\
\hline 6 & Visual Gerak & $\begin{array}{l}\text { Film bingkai (slide) bersuara } \\
\text { Film bisu }\end{array}$ \\
\hline 7 & Visual gerak & $\begin{array}{l}\text { Audio Visual gerak Film gerak } \\
\text { bersuara, video/VCD, Televisi }\end{array}$ \\
\hline 8 & Obyek fisik & $\begin{array}{l}\text { Benda nyata, model, specimen, } \\
\text { Manusia, binatang, tumbuhan, } \\
\text { dan benda lain }\end{array}$ \\
\hline 9 & $\begin{array}{l}\text { Manusia \& ling- } \\
\text { kungan }\end{array}$ & $\begin{array}{l}\text { Guru, Pustakawan, Laboran, } \\
\text { Alam sekitar, profesi, aktivitas } \\
\text { manusia, }\end{array}$ \\
\hline 10 & Komputer & $\begin{array}{l}\text { CAI (pembelajaran berbantuan } \\
\text { komputer), CBI (pembelajaran } \\
\text { berbasis komputer) }\end{array}$ \\
\hline
\end{tabular}

Penyusunan media pembelaja- dia pembelajaran yang baru atau beran dapat diartikan menciptakan me- lum pernah ada, sedangkan pengem- 
bangan media pembelajaran dapat diartikan sebagai upaya mengadaptasi, merekayasa, atau menyesuaikan (modifikasi) media pembelajaran yang sudah ada dengan kebutuhan dalam proses pembelajaran. Dalam proses pembelajaran seringkali tidak dilengkapi dengan media pembelajaran yang memadai. Oleh karena itu, pendidik (fasilitator) ataupun pengelola/penyelenggara program dituntut untuk mampu merancang, menyusun atau mengembangkan media yang digunakan dalam proses pembelajaran yang dikelolanya. Secara garis besar atau pada umumnya, proses penyusunan atau pengembangan media pembelajaran meliputi langkah-langkah sebagai berikut (Departemen Pendidikan Nasional, 1989/1990)

a. Identifikasi kebutuhan belajar warga belajar

b. Penentuan prioritas kebutuhan belajar warga belajar

c. Perancangan program belajar (kurikulum)

d. Penentuan topic

e. Penentuan jenis atau golongan media pembelajaran

f. Pengorganisasian isi/materi dan bahan yang diperlukan

g. Penyusunan atau pengembangan draft media pembelajaran

h. Penyusunan instrumen ujicoba draft media pembelajaran

i. Ujicoba draft media pembelajaran

j. Revisi draft media pembelajaran

k. Produksi media pembelajaran

1. Distribusi dan penggunaan media pembelajaran pada kelompok belajar

$\mathrm{m}$. Evaluasi media pembelajaran

n. Revisi media pembelajaran (jika memerlukan)

3. Media Sosial Dalam Proses Pembelajaran Di Perguruan Tinggi
Perkembangan teknologi informasi yang begitu cepat sangat mempengaruhi paradigma pengembangan media pembelajaran. Pergeseran tersebut dapat kita potret dari perubahan penggunaan media pembelajaran, dimana sebelumnya hanya bisa dimanfaatkan apabila antara pengajar dan yang diajar berada pada tempat dan waktu yang sama. Saat ini dalam perkembangannya, setelah media pembelajaran berhasil dibuat, dalam proses penyampaiannya tidak hanya dapat diberikan secara bertemu langsung atau tatap muka, melainkan dapat diberikan atau disampaikan dengan cara tidak bertemu secara langsung. Internet dapat mengatasi masalah jarak dan waktu dalam proses pembelajaran. Pada Perguruan Tinggi internet dapat merangsang para dosen dan mahasiswa menjadi lebih aktif dalam memanfaatkan media pembelajaran yang berbasis teknologi informasi.

Media sosial sebagai bagian yang tidak dapat dipisahkan dari internet telah menjadi tren baru di masyarakat. Penggunaannya yang begitu masif juga dapat dimanfaatkan dalam mendukung proses pembelajaran di perguruan tinggi. Media sosial memiliki beberapa kelebihan diantaranya mudah untuk digunakan, membangun hubungan atau relasi, jangkauanya global, dan terukur. Selain e-learning, perguruan tinggi dapat memanfaatkan media untuk sharing materi, diskusi, maupun tanya jawab. Berikut ini adalah beberapa contoh pemanfaatan media sosial untuk menunjang proses pembelajaran :

1. Tugas Kelompok Menggunakan Grup Facebook

Mahasiswa dapat membuat grup facebook untuk dapat berdiskusi secara online sesuai dengan pendidikan mereka. Dosen juga dapat mereka masukan sebagai member grup untuk 
memberikan arahan dan masukan terhadap topik yang sedang mereka diskusikan. Grup tidak saja dapat mereka gunakan untuk berdiskusi, melainkan juga dapat mereka gunakan berkolaborasi yaitu saling berbagi materi atau bahan diskusi berupa file multimedia diantaranya gambar, suara, dan teks. Mereka juga dapat mengundang professional bidang tertentu menyesuaikan dengan topic.

\section{Konferensi Video Kelas}

Menggunakan Google Hangout.

Google Hangouts merupakan platform untuk melakukan chat video dengan orang banyak dalam waktu yang bersamaan. Dengan Google hangouts, mahasiswa yang tidak bisa hadir dikelas masih tetap bisa mendapatkan pelajaran dari jarak jauh dan masih bisa berpartisipasi dalam kelas. Diluar jam belajar, para siswa juga bisa membentuk konferensi video untuk berdisukusi tentang materi pembelajaran. Dosen yang mengajar mata kuliah yang sama pada kelas yang berbeda dapat memanfaatkan fitur ini untuk menjaga konsistensi dalam proses pembelajaran.

3. The Flipped Classroom Menggunakan Youtube.

The Flipped Classroom adalah konsep baru yang mengubah cara mengajar konvensional menjadi lebih efisien dengan memanfaatkan platform Youtube. Mahasiswa dapat mencari sendiri materi yang berkaitan dengan materi yang akan diberikan sebelum materi tersebut dibahas di kelas. Dosen juga dapat membagikan materi berupa turorial video melalui channel youtube yang dimilikinya. Bahkan antara dosen dan mahasiswa dapat saling berbagi channel yang dimiliki masing-masing sehubungan dengan materi yang dibahas dalam proses pembelajaran.
4. Jaringan Industri Menggunakan
Linkedln.

Salah satu tujuan mahasiswa belajar adalah bekerja setelah tamat kuliah. Jejaring sosial yang dapat mereka manfaatkan untuk mendapatkan pekerjaan yang sesuai dengan pendidikan adalah linkedln. LinkedIn memberikan fasilitas penggunanya untuk mencari pekerjaan yang relevan sesuai dengan latar pendidikan dan minat yang diambil. Disini para siswa bisa memasukan data diri dan menambah relasi dari berbagai kalangan, baik itu teman ataupun kalangan pekerja Industri..

5. Q \& A Menggunakan Twitter / Reddit.

Banyak professional di bidang pendidikan memanfaatkan twitter dan reddit membuka sesi tanya jawab dengan para followernya yang berkaitan dengan pengetahuan dan pendidikan jenjang berikutnya. Reddit adalah situs media sosial tempat penggunanya melakukan diskusi. Mereka dapat saling menanggapi satu sama lain untuk saling melengkapi pengetahuan mereka. Mahasiswa tentunya juga dapat memnfaatkan Reddit untuk berdiskusi mengenai masalah yang terkait dengan materi yang sedang mereka pelajari.

6. Penelitian dan Debat Menggunakan Quora.

Quora adalah jejaring sosial yang dikembangkan secara khusus untuk meningkatkan pengetahuan melalui sharing informasi. Siswa yang perlu meneliti topik tertentu hanya dapat mengakses opini dan studi sesuai dengan minat yang telah ditetapkan. Tidak hanya untuk menemukan pertanyaan dan jawaban, mereka juga dengan mudah bisa mengakses banyak konten dari para ahli di berbagai Industri, sehingga mereka mendapat pengetahuan yang komprehensif untuk digunakan dalam penelitiannya.

7. Pengembangan Kesenian dan Ke- 
rajinan Tangan - Pinterest.

Selain didalam kelas, siswa harus mencari cara untuk mengembangkan keterampilan seni dan kerajinan. Pinterest merupakan situs yang cocok untuk menjadi sumber informasi seputar topik artistik dan kreatif. Pinterest juga bisa dijadikan inspirasi untuk kegiatan yang berhubungan dengan seni karena kontennya yang sangat beragam dan terkumpul dari seluruh belahan dunia (Ana Nursyifa, $\quad$ http://www.pikiranrakyat.com/pendidikan/2017/06/06/7jejaring-sosial-untuk-media-belajarsiswa-402597, diakses 25 Pebruari 2018)

Para pengajar seperti guru dan dosen dapat memanfaatkan media sosial untuk mendukung proses pembelajaran merupakan hal yang sangat positif. Cara seperti juga dapat mengurangi penggunaan media sosial untuk hal-hal yang negative karena perhatian para siswa dan mahasiswa dialihkan para materi pembelajaran yang dibagi dan dibahas melalui media sosial.

Penggunaan media sosial sebagai media pembelajaran memudahkan dosen dan mahasiswa melihat kembali tentang apa yang mereka telah bahas. Mereka dapat baca dan pelajari secara berulang-ulang materi yang telah dibahas karena media sosial dapat menyimpan semua yang telah dibuat baik itu materi maupun diskusi yang telah dilakukan. Mereka juga dapat mengumpulkan semua materi yang telah dibagikan dan dibahas menjadi catatan bahkan buku untuk referensi dan kontribusi terhadap pengembangan ilmu pengetahuan. Kita dapat melihat salah satu contoh pemanfaatan positif media sosial seperti facebook adalah terbitnya buku digital yang dijual melalui google book dengan judul Fakultas Kehidupan di Media Sosial (Kumpulan Kata-Kata Motivasi dan Kata-Kata Bijak di Facebook), karya Rospita. Buku ini merangkum beberapa kata-kata motivasi dan katakata bijak yang selama ini penulisnya berbagi di media sosial khususnya facebook. Dosen dan mahasiswa diharapkan dapat lebih memanfaatkan teknologi yang ada ini untuk keberhasilan proses pembelajaran di perguruan tinggi.

\section{KESIMPULAN}

Media sosial sangat bisa dipergunakan untuk berbagi media pembelajaran karena media sosial mendukung berbagai jenis file multimedia yang dibagikan seperti teks, gambar, video, dan animasi. Proses pembelajaran mulai dari sharing materi, diskusi, pengumuman dapat dilakukan dengan memanfaatkan situs dan aplikasi media sosial. Ketersediaan perangkat yang dipergunakan dimiliki oleh seluruh kalangan, terutama anak muda yang masih menjadi mahasiswa. Kecenderungan ini dapat dimanfaatkan oleh penggiat pendidikan terutama dosen untuk membantu pelaksanaan tugasnya secara lebih efektif dan efisien.

Media sosial dapat dipergunakan secara positif maupun negatif, daripada pemanfaatannya untuk hal-hal yang dapat menghancurkan peradaban manusia, sebaiknya para dosen diperguruan tinggi lebih banyak memanfaatkan media sosial untuk mendukung proses pembelajaran sehingga tujuan penyelenggaraan pendidikan dapat tercapai.

\section{DAFTAR PUSTAKA}

Feri Sulianta, 2015, Keajaiban Sosial Media, PT Elex Media Komputindo, Jakarta

Hasanah Nur, 2008, "Pengembangan Media Pembelajaran Berbasis 
ICT Dalam Proses Belajar Mengajar Di Perguruan Tinggi, Jurnal Elektronika Telekomunikasi Dan Computer Vol.3, No. 1, Desember 2008

Latuheru, JD. 1988. Media Pembelajaran dalam Proses Belajar Masa. Kini, Depdikbud, Jakarta

Rospita, 2017, judul Fakultas Kehidupan di Media Sosial (Kumpulan Kata-Kata Motivasi dan Kata-Kata Bijak di Facebook), Masiva Indonesia, Yogyakarta.

Syaiful Bahri Djamarah, 2005, Guru dan Anak Didik dalam Interaksi edukatif : Suatu Pendekatan Teoretis dan Psikologis, Edisi Revis Rineka Cipta, Jakarta.

https://kominfo.go.id/index.php/ content/detail $/ 3415 /$ Kominfo $+\%$ $\underline{3 \mathrm{~A}+\text { Pengguna }+ \text { Internet }+\mathrm{di}+\text { Indo }}$ $\underline{\text { nesia }+63+\text { Juta }+ \text { Orang/0/ }}$ berita satker

Hardy,

www.progresstech.co.id/blog/ jenis-sosial-media

Ana Nursyifa, http://www.pikiranrakyat.com/pendidikan/2017/06/06/7jejaring-sosial-untuk-media-belajarsiswa-402597. 